\title{
A ECONOMIA CRIATIVA E DO CONHECIMENTO NA COMPETITIVIDADE DAS CIDADES EUROPEIAS
}

SORAIA SILVA ${ }^{1}$

Em 2010, foi publicado o livro Making Competitive Cities ${ }^{\mathrm{i}}$, que apresenta os principais resultados do projecto de investigação europeu ACRE - Accommodating Creative Knowledge, financiado pelo FP6 da UE, que decorreu entre 2007 e 2010, envolvendo equipas de cientistas sociais em treze cidades europeias: Amesterdão, Barcelona, Birmingham, Budapeste, Dublin, Helsínquia, Leipzig, Milão, Munique, Poznan, Riga, Sófia e Toulouse. O geógrafo Sako Musterd, da Universidade de Amesterdão, foi o coordenador.

O objectivo central da investigação consistiu em identificar as condições que permitem o desenvolvimento das cidades criativas [e] do conhecimento ${ }^{\text {ii }}$ na Europa, aplicando uma metodologia comum a todos os casos, incluindo a análise documental e estatística de dados secundários e a realização de entrevistas e inquéritos. O livro foi organizado em cinco partes, de acordo com os grandes parâmetros metodológicos utilizados, indo muito além da junção e organização dos relatórios parcelares preparados por cada uma das equipas (que podem ser consultados na página do projecto http://acre.socsci.uva.nl/index.html) e propondo, ao longo dos diversos capítulos, uma comparação imediata entre algumas das cidades, salientando como é que aspectos cruciais se revelam em diferentes contextos urbanos.

A parte I - Introdução - é composta por dois capítulos. O primeiro faz uma sinopse teórica, empírica e metodológica do livro, posteriormente mais desenvolvida. No capítulo 2 é apresentado um enquadramento teórico sobre as condições de competitividade das cidades, agrupado em quatro grandes blocos: as teorias clássicas de localização, que focam as condições hard no desenvolvimento dos territórios; a teoria dos clusters, que salienta o papel das economias de aglomeração; as redes pessoais, que relevam a imbricação dos agentes em contextos específicos e a path dependency dos territórios; por último, a teoria das condições soft, que se refere às amenidades das cidades e ao modo como estas atraem a 'classe criativa'.

Na Parte II - Percursos - são analisados os aspectos mais relevantes dos percursos de desenvolvimento das cidades. O capítulo 3 apresenta uma reflexão teórica sobre o assunto, que sustenta as hipóteses da análise, compostas por diferentes pilares: (i) cidades que se constituem como centros de poder políticos e económicos, (ii) centros histórico-culturais e educacionais, (iii) cidades especializadas em indústrias altamente qualificadas ou tecnológi-

1 Bolseira de Investigação Científica, do Núcleo de Estratégias e Políticas Territoriais (NEST) do CEG. Email: soraiasilva@campus.ul.pt 
cas e (iv) cidades vocacionadas desde cedo para o sector terciário, são as que reúnem em princípio, as melhores condições para o desenvolvimento dos sectores criativos e do conhecimento. O capítulo 4 retrata os casos de Amesterdão, Munique e Milão. Estas cidades foram agrupadas por serem consideradas líderes na economia criativa e do conhecimento na Europa, o que em muito se deve à sua localização geográfica e à sua antiga centralidade económica e cultural. No capítulo 5, são analisadas Barcelona, Birmingham e Dublin, como casos de sucesso na transformação da economia e reinvenção da imagem urbana, processos em que as políticas públicas tiveram um papel crucial. O capítulo 6 agrupa Budapeste, Leipzig, Poznan, Riga e Sófia, sob a premissa de terem tido um começo tardio em termos de investimento nos sectores criativos e do conhecimento, devido ao seu percurso político, o que se traduz, por exemplo, ainda actualmente, em fortes debilidades institucionais, situação que se apresenta como um dos seus principais desafios. O capítulo 7 retrata as cidades de Helsínquia e Toulouse, que têm em comum a grande especialização (recente) em sectores tecnológicos e o investimento público em I\&D, educação e ciência e, também, a rápida restruturação dos tecidos económico e social nas últimas décadas, permitindo as trajectórias subsequentes.

A Parte III - Actores - é dedicada à análise empírica dos resultados das entrevistas e inquéritos. $\mathrm{O}$ capítulo 8 introduz a relevância dos três grupos de agentes avaliados, associados aos sectores criativos e do conhecimento: os empreendedores e gestores de empresas, normalmente relacionados com modelos decorrentes das teorias clássicas de localização e de clusters, trabalhadores altamente qualificados e migrantes transnacionais, associados às teorias das condições soft. $\mathrm{O}$ capítulo 9 trabalha sobre o primeiro grupo nas cidades de Helsínquia, Toulouse, Budapeste, Riga e Sófia, concluindo que as escolhas de localização dos empreendedores e gestores estão maioritariamente relacionadas com laços familiares e territoriais e que apenas em segundo lugar se torna útil separar as condições hard e soft, sendo as primeiras mais relevantes para explicar os percursos individuais do que as segundas. $\mathrm{O}$ capítulo 10 agrega a análise dos migrantes transnacionais em Amesterdão, Barcelona, Dublin e Munique, reforçando a ideia de que os factores hard se revelam mais significativos que os soft (com excepções em Barcelona) e evidenciando também outros factores relevantes como as políticas nacionais de migração e o papel das redes familiares e tradicionais de migração. O capítulo 11 retrata os jovens trabalhadores altamente qualificados em Amesterdão, Milão e Barcelona. Os autores concluíram que estes profissionais são pouco móveis, permanecendo nas cidades onde já possuem relações pessoais prévias e onde as instituições educativas têm um papel determinante na retenção de licenciados. O capítulo 12 discute as condições laborais dos trabalhadores criativos e do conhecimento nas cidades de Birmingham, Leipzig e Poznan, evidenciando a insegurança e precariedade da maioria das situações laborais analisadas, embora muitos dos inquiridos indicassem, paradoxalmente, elevada satisfação ao nível da realização pessoal.

A Parte IV - Políticas - analisa criticamente as estratégias políticas e económicas que têm sido aplicadas nas cidades em estudo. No capítulo 13 é referido que, à luz dos resultados preliminares, os decisores devem pensar as políticas públicas para a competitividade de forma integrada e não numa perspectiva sectorial que separe, por exemplo, as orientações económicas, da política cultural ou do ordenamento do território. O capítulo 14 apresenta os casos de Dublin, Toulouse e Milão, onde os principais desafios se prendem com a conjugação de objectivos de solidariedade social e espacial com os de competitividade, sobretudo em Milão, onde a falta de confiança nas instituições públicas torna mais premente essa articulação. O capítulo 15 apresenta os casos de Birmingham, Poznan e Helsínquia enquanto exemplos da aplicação das políticas de clusters, concluindo que o seu sucesso é amplamente deter- 
minado pela conjugação de políticas económicas locais/regionais e nacionais, e pela presença de outros factores de sucesso aos níveis local e regional. O capítulo 16 trata três cidades que 'querem' ser criativas: Amesterdão, Munique e Budapeste. Embora com percursos distintos, as principais semelhanças identificadas prendem-se com a prioridade dada pelas políticas públicas aos factores hard. $\mathrm{O}$ capítulo 17 diz respeito às formas de governança emergentes nas cidades de Leipzig, Barcelona e Sófia, salientando as diferenças entre a maior auto-organização nas actividades artísticas e a maior formalidade top-down nos sectores intensivos em conhecimento, embora o financiamento público seja sempre fundamental e as políticas tendam a valorizar a criação de redes e contextos informais de criação e troca de conhecimento.

Por último, a Parte V - Síntese - é composta por um único capítulo em que são destacadas as principais conclusões do estudo, nomeadamente: a importância do percurso histórico, político, económico e social de cada cidade até ao presente e o planeamento do futuro; o relevo que a existência prévia de redes pessoais tem nas trajectórias individuais, sobrepondo-se às condições hard e soft; as primeiras continuam contudo a ser preponderantes, enquanto as segundas actuam sobretudo como factor de retenção; não parece existir uma classe criativa altamente móvel nas cidades europeias, ao contrário do que se verifica na América do Norte, o que deve associar-se a diferenças culturais de base; finalmente, salientase a necessidade de pensar nas políticas públicas de forma sectorialmente integrada e multiescalar.

Musterd S, Murie A (eds.) (2010) Making Competitive Cities. Wiley-Blackwell, Oxford.

ii No original, os autores utilizam a expressão "creative knowledge cities". 